University of Wollongong

Research Online

Faculty of Law - Papers (Archive)

Faculty of Business and Law

$1-1-2009$

\title{
Fakers and Forgers, Deception and Dishonesty: An Exploration of the Murky
} World of Art Fraud

Kenneth Polk

University of Melbourne

Duncan Chappell

University of Wollongong, duncanc@uow.edu.au

Follow this and additional works at: https://ro.uow.edu.au/lawpapers

Part of the Law Commons

\section{Recommended Citation}

Polk, Kenneth and Chappell, Duncan: Fakers and Forgers, Deception and Dishonesty: An Exploration of the Murky World of Art Fraud 2009, 393-412.

https://ro.uow.edu.au/lawpapers/73

Research Online is the open access institutional repository for the University of Wollongong. For further information contact the UOW Library: research-pubs@uow.edu.au 


\title{
Fakers and Forgers, Deception and Dishonesty: An Exploration of the Murky World of Art Fraud
}

\author{
Abstract \\ This article examines the problem of fraud in the contemporary art market. It addresses two major cases \\ where persons have been convicted of art fraud in recent years in Australia, examining the legal context \\ within which the prosecutions took place. It then examines problems in common terms such as 'forgery' \\ and 'fakery'. The final sections review the different ways that issues of authenticity in art are addressed in \\ possible cases of art fraud, and examines the question of why so little art fraud comes to the attention of \\ the criminal justice system.

\section{Keywords} \\ dishonesty, murky, world, fakers, forgers, deception, exploration, art, fraud \\ Disciplines \\ Law

\section{Publication Details} \\ D. Chappell \& K. Polk, Fakers and Forgers, Deception and Dishonesty: An Exploration of the Murky World \\ of Art Fraud, Current Issues in Criminal Justice, 20(3), 2009, 393-412.
}




\title{
Fakers and Forgers, Deception and Dishonesty: An Exploration of the Murky World of Art Fraudt
}

\author{
Duncan Chappell ${ }^{*}$ and Kenneth Polk ${ }^{* *}$
}

\begin{abstract}
This article examines the problem of fraud in the contemporary art market. It addresses two major cases where persons have been convicted of art fraud in recent years in Australia, examining the legal context within which the prosecutions took place. It then examines problems in common terms such as 'forgery' and 'fakery'. The final sections review the different ways that issues of authenticity in art are addressed in possible cases of art fraud, and examines the question of why so little art fraud comes to the attention of the criminal justice system.
\end{abstract}

\section{Introduction}

Art fraud, especially allegations of the circulation of spurious works of art, seems a common topic for contemporary mass media. Certainly, the present writers, as criminologists, have encountered numerous allegations of false works in the art market in our many interviews and contacts with leading figures in the Australian context over the past decade. At the same time, as we shall see, almost no cases of art fraud work their way through the court system, either in this country or overseas. This suggests that there may be significant barriers within the criminal justice system that make it difficult to prosecute successfully this form of fraud. The purpose of the present discussion is to examine the crime of art fraud in terms of the major elements that have to be established for a prosecution of the crime, based in large part upon two recent Australian prosecutions of this type which have been successful, and then go on to examine some of the reasons why such prosecutions are so rare.

\footnotetext{
The authors wish to express their gratitude to Judge Stephen Norrish of the District Court of NSW, Gayle Davies of the Office of the NSW Director of Prosecutions, and Charlotte Duckett of the Office of the Public Prosecutor in Victoria, for the invaluable assistance they provided in obtaining access to court transcripts and allied material relating to the cases of O'Loughlin and Liberto. It is emphasised that all of the views expressed in this article are those of the authors alone.

- Professorial Fellow, Centre for Transnational Crime Prevention, University of Wollongong, and Adjunct Professor, Sydney University Law School. Email: chappell@abigpond.net.au; postal address: Center for Transnational Crime Prevention, University of Wollongong, NSW 2522.

- Professor of Criminology, University of Melbourne. Email: k.polk@unimeld.edu.au; postal address: 50 Smith Street, Brunswick West, Victoria 3055.
} 


\section{The Art Fraud Legal Tool Box}

\section{The State of the Law of Fraud}

When lifting the lid on the art fraud legal tool box at their disposal investigators and prosecutors will be confronted by one of the most technical, complex and in many cases arcane areas of the criminal law. In Australia alone each of the nine federal, state and territorial jurisdictions across the nation continue to operate under their own often quite disparate sets of laws, even though large and sophisticated fraud cases, including art fraud, frequently involve multiple jurisdictions and offenders. These dilemmas become even more intense when any attempt is made to describe the comparative approaches to fraud taken in other common law jurisdictions like the United States and United Kingdom.

A bold but failed attempt was made in Australia in the 1990s to achieve the introduction of uniform laws relating to fraud and allied offences (Model Criminal Code 1995). As the framers of the Model Criminal Code remarked at the time:

Inexperienced police officers can be confronted with a choice between a myriad of specific theft or fraud type offences cobbled together over the years to plug gaps in the pre exiting law. For example, the New South Wales Crimes Act contains a multitude of offences relating to fraud and theft. Often the choices involve excessively technical distinctions about which offence is the correct one to choose. These choices can dog the case from the charge decision to committal, to drawing the indictment, to the judge's charge to the jury, to the jury's decision over which charge, if any, to conviction (Model Criminal Code 1995:v).

A successful traversing of this legal minefield will obviously require considerable skill and expertise on the part of investigators and prosecutors, regardless of the nature of the fraud under consideration. Even so, there are likely to be a number of common evidentiary issues and elements which will need to be present before any fraud investigation or prosecution can proceed, namely, there is (i) some form of deception by a defendant and (ii) this deception has produced some form of harm (iii) to a victim who was in fact deceived and (iv) there was some level of knowledge, intent, or dishonesty on the part of the defendant (see in general Lanham et al 1987). The precise charge(s) which may flow from any fraud investigation will depend very much upon the particular evidentiary mix surrounding these four elements, and the peculiarities of the fraud law in any given jurisdiction.

Of these four elements that need to be addressed for a prosecution, the first, proof of deception, is the one that provides the clearest identity to the problem of art fraud. The case will depend upon the prosecution establishing that an art object is deceptive, that is, it is not authentic. It is virtually inevitable that the proof for this claim will be provided by experts from the field of art. They are likely to draw upon three procedures for determining if a given work is authentic: (1) review of the provenance of the object (that is, its history of ownership), (2) scientific analysis of the work itself (for example, a chemical analysis of the pigments of a painting to establish if the paints used are consistent with those available at the time the painting was claimed to have been done), and (3) stylistic analysis of the work to establish if the elements of the work are consistent with the known style of the artist (for a discussion of these, see O'Connor 2004:6; Flescher 2004:98).

The second element, harm, requires that the prosecution establish that the victim suffered in the sense of experiencing a financial loss. In most circumstances of art fraud this loss will be a direct monetary loss in the form of a sum paid for a non-authentic art work which was believed to be authentic. 
The third element, most often not a major issue in art crime, requires that it be established that the victim was in fact deceived. However, it may take some time for such deception to become a reality as most successful cases of art fraud from the fraudster's perspective are of a serial form and the non-authenticity of a number of works entering the legitimate art market may not be detected for many months or even years.

The fourth element, intent or dishonesty, requires that the prosecution establish that the defendant intentionally claimed that the object was something that it was not. As explained in more detail below considerable controversy continues in legal circles about the meaning of the term 'dishonesty' in the general context of fraud cases, although in most instances of art fraud establishing the requisite intent is usually not the central issue.

We turn now to consider two cases of art fraud which have been brought before the courts in Australia over the past decade - one in NSW (O'Loughlin 2002) and the other in Victoria (Liberto 2008). As we shall see each case resulted in conviction of the accused persons of fraud related offences.

\section{O'Loughlin}

John O'Loughlin, an Adelaide art dealer, had a long association with the famous Aboriginal artist, Clifford Possum Tjapaltjarri. The association included a commercial arrangement by which Clifford Possum produced paintings for O'Loughlin which were bought by him and then on sold to other dealers and individuals across the country.

In February 1999 Clifford Possum visited a gallery in Sydney where a number of paintings attributed to him were being displayed for sale. Upon inspection of the paintings Clifford Possum identified a number which he said were not produced by him. The gallery owner indicated that he had obtained the paintings from O'Loughlin. Subsequently, Clifford Possum also identified paintings falsely attributed to him which were in the hands of the NSW Art Gallery and the Museum of Contemporary Art, all of which had passed through O'Loughlin's dealership.

After an extensive multi-jurisdictional police investigation O'Loughlin was arrested by South Australian police in October 1999 and extradited to NSW where he was charged with a number of offences under the provisions of s178BA of the Crimes Act 1900 (NSW). Section 178BA provides, in part:

(1) Whosoever by any deception dishonestly obtains for himself or herself or another person any money or valuable thing or any financial advantage of any kind whatsoever shall be liable to imprisonment for 5 years.

(2) In subsection (1) deception means deception (whether deliberate or reckless) by words or conduct as to fact or as to law ...

Each of the offences with which O'Loughlin stood charged related to his alleged sale over a number of years of paintings which purported to be the work of Clifford Possum but which were in fact falsely attributed to him. To establish these charges the Crown had to establish each of the elements of the offence contained in s178BA, namely, to show beyond a reasonable doubt that $O$ 'Loughlin had (i) by a deception (ii) dishonestly obtained for himself (iii ) money/valuable things/ or any financial advantage.

In regard to element (i), an essential ingredient of the offence was to show a direct linkage between the deceptive conduct of the accused person and the obtaining of the alleged benefit - in this case the money paid by the buyers for the works offered to them by O'Loughlin (see Howe \& Johnson 2008:878). The alleged deception used by O'Loughlin 

was that he represented by words and conduct that the paintings he had for sale were produced by Clifford Possum. It was also contended that this deception was made dishonestly (element (ii)), O'Loughlin knowing that the paintings were not produced by Clifford Possum. Finally, in regard to element (iii) it was said O'Loughlin had obtained a substantial financial advantage through the sale of the paintings although the precise amounts involved remained unclear.

The evidence revealed at O'Loughlin's committal proceedings was sufficient to have him committed for trial on the charges brought under s178BA. However, the Crown then settled upon an indictment on alternative charges under s178BB of the Crimes Act (NSW). This section provides, in part:

Whosoever, with intent to obtain for himself or herself or another person any money or valuable thing or any financial advantage of any kind whatsoever, makes or publishes, or concurs in making or publishing, any statement (whether or not in writing) which he or she knows to be false or misleading in a material particular and is made with reckless disregard as to whether it is true or false or misleading in a material particular shall be liable to imprisonment for 5 years.

Why did this alteration in the charges take place? No direct explanation is to be found in the account of the official proceedings which led to O'Loughlin pleading guilty in November 2000 to five charges laid under s178BB, with a further five charges being taken into account by the court at the time of sentence. It may be surmised, however, that the prosecution was uncertain about its ability to establish that he had not only engaged in deceptive behaviour but that he did so 'dishonestly'- the essential mental ingredient in fraud offences.

In Australia, as we have mentioned earlier, substantial controversy and debate continues among legal scholars concerning the concept of dishonesty (see in general Bronitt \& McSherry 2001:677-689). In NSW this concept is not defined by statute but at common law; as a result of the High Court decision of Peters (1998), the test is presumed to be an objective one - conduct is criminally dishonest if the fact finder (the jury, or a judge in a non-jury trial) concludes that 'ordinary, decent people' would consider the conduct to be dishonest (Howe \& Johnson 2008:879). This test is in contrast to that proposed in the Model Criminal Code 1995, and adopted in recent amendments to the Crimes Act 1995 (Cth) where it is stated that dishonest means 'dishonest according to the standards of ordinary people', and 'known by the defendant to be dishonest according to the standards of ordinary people' (Crimes Act 1995 (Cth) s480.2).

This latter test, which remains one to be applied by the fact finder, has been labelled the 'ordinary meaning approach' and is based upon the views expressed in two English decisions - Feely (1973) and Ghosh (1982). It is a test which has been subjected to severe criticism, not the least in Victoria where the courts have refused to follow this approach on the basis that it is likely to produce 'endemic inconsistency' if juries are permitted to decide what is or is not to be the standard of honesty in the community ( $R v$ Salvo (1980); see discussion by Bronitt \& McSherry 2001:678). Thus in Victoria dishonesty is a matter of law to be determined by the courts and means obtaining property 'without any belief that the accused has any legal right to deprive the other of it' (Salvo at 432).

Although this legal jousting was not on display in the O'Loughlin case it is clear from the decision that the element of dishonesty was on the mind of the judicial officer presiding over the sentencing proceedings, District Court Judge Norrish, who expressed a number of concerns about the nature of the evidence surrounding the production of certain of the paintings alleged to be falsely attributed to Clifford Possum. For example, in regard to one painting a photograph was exhibited of Clifford Possum signing his name at the bottom of 

the painting. According to testimony given by Possum this was an instance where he had been paid to sign paintings and did so either because he was scared and/or drunk. In another case Possum was said to have signed the back of a canvas, leaving the detail to be filled in by others, including O'Loughlin. Judge Norrish noted that there was ample evidence to support the proposition that Indigenous artists' practice and ownership accepted the concept of assistance in the production of art works. More is said about this practice below, and the attribution problems it presents.

Judge Norrish concluded that in regard to the issues he had to deal with he found it very difficult to decide where the truth lay. He indicated that he could not make a positive finding that O'Loughlin did not believe that he had some authority from Clifford Possum to work on paintings bearing the artist's motifs. He could also find no evidence to conclude that O'Loughlin had inflicted any specific financial hardship or financial deception on Possum.

If the prosecution had elected to proceed on the original charges these and other evidentiary flaws identified by Judge Norrish could have proven fatal to the Crown's case. Thus the decision to drop these original charges in favour of those brought under s178BB was a prudent one since the new offences, unlike their predecessors, did not require the prosecution to establish the element of dishonesty referred to above. In Judge Norrish's words:

While the Crown does not eschew an allegation that the prisoner acted dishonestly, in the general sense, proof of dishonesty is not an essential element of the charge now being brought against the prisoner. The issue is whether the conduct of the prisoner was misleading in a material sense with or without the element of dishonesty. The prisoner has pleaded guilty on the basis that the misleading statement was an implied representation that the painting had been completely painted by Clifford Possum. I accept the prisoner's plea of guilty to be in fact an acknowledgement of the fact that he knew that the paintings were not completely painted by Clifford Possum and represented those paintings too have been completely painted by Clifford Possum notwithstanding this knowledge. That would be sufficient to complete the commission of the offence ( $O^{\prime}$ Loughlin at 21-22).

On 23 February 2002, O'Loughlin was sentenced by Judge Norrish to a good behaviour bond for a period of three years - a penalty which may be judged by some to be quite lenient given the systemic nature of the deceptive conduct displayed by O'Loughlin, and the extensive law enforcement resources required to bring the case to trial in the first place. Even so, the case does represent a landmark in the murky world of art fraud, representing the first occasion on which a successful prosecution has been achieved in this country against a major category of white collar or organised crime which, as will be indicated in more detail shortly, is still largely unrecognised and unreported. The $O^{\prime}$ Loughlin case also begins to illustrate the complexities of the legal and evidentiary burdens confronting those seeking to change this situation.

\section{Liberto}

In 2007 a further landmark Australian art fraud case emerged in Victoria in the form of Liberto. As in $O^{\prime}$ Loughlin the false art works involved were those claimed to be produced by a famous Aboriginal artist, in this case Rover Thomas who died in 1998. Over a period of several years a Melbourne couple, Pamela Yvonne Liberto and her husband Ivan Liberto, were alleged to have either sold or attempted to sell a number of paintings reputedly produced by Thomas for a total sum exceeding $\$ 300,000$. The sales were made principally through well known international art auction houses like Christie's and Sotheby's, having been assessed as being genuine works of Thomas by art experts employed by these companies. 
Suspicion about the authenticity of the paintings was only raised in September 2005 when the head of Sotheby's Aboriginal art section, Timothy Klingender, was approached by the Libertos to sell a painting of a rainbow serpent, said to be the work of Thomas. Klingender compared a photo of the painting with that of another similar Thomas painting that had been sold for the Libertos by Sotheby's in 2004. He then contacted an expert at the University of Melbourne, Robyn Sloggett, who subjected the painting to tests and determined that it was not authentic. Police were then alerted and later raided the Libertos' home in March 2006, finding there two partly completed Thomas' paintings as well as other materials and catalogues associated with this artist (see in general Hagan 2007a, 2007b, 2007c).

The Libertos were charged with two counts of attempting to obtain money by deception dishonestly and four counts of obtaining money by deception dishonestly between May 2002 and March 2006. The charges were brought under the provisions of s81 of the Victorian Crimes Act 1958 which provides, in part:

(1) A person who by any deception dishonestly obtains property belonging to another, with the intention of permanently depriving the other of it, is guilty of an indictable offence and liable to level 5 imprisonment (10 years maximum)

(2) For the purposes of this section a person is to be treated as obtaining property if he obtains ownership, possession or control of it, and obtain includes obtaining for another or enabling another to obtain or to retain ....

(4) For the purposes of this section, deception -

(a) means any deception (whether deliberate or reckless) by words or conduct as to fact or law, including a deception as to the present intentions of the person using the deception or any other persons ...

The vital elements of the offence of obtaining property by deception under $\mathrm{s} 81$ of the Victorian Crimes Act 1958 are in essence the same as those referred to earlier in regard to s178BA of the NSW Crimes Act 1900 - proof beyond a reasonable doubt that the accused obtained property (in the Liberto case money) by means of a deception, and dishonestly (see in general Lanham et al 1987:64-76).

The statutory definition given in the Victorian legislation of deception is not dissimilar from the NSW definition noted above, and it remains a core requirement of the offence to establish that the false representation or deception made by the accused actually deceived the victim and caused the handing over of the property involved. Thus in the case of the Libertos it had to be shown that the various auction houses and individual purchasers of the paintings were deceived about their authenticity. If, on the other hand, these victims knew that the paintings were false, or would have acted in the same way even had they known they were false, or did not rely upon any deceptive conduct but had decided independently to proceed to purchase them, the Libertos could not be convicted of obtaining by deception, although they possibly could be convicted of an attempt to obtain by deception (Lanham et al 1987:71).

Mention has already been made of the legal controversy surrounding the meaning of the word 'dishonestly' which is also a major element of the offence of obtaining property by deception. Reference has also been made to the approach taken by the Victorian courts to the definition of this element within that jurisdiction. However, in Liberto this definition was not of critical importance to the successful prosecution of the two accused who elected to plead not guilty to all of the charges, in doing so denying that any of the paintings they had sold or attempted to sell were other than genuine works by Rover Thomas. 
Given this plea the central issue in their trial became that of the authenticity of the works - an issue which is central to most cases of alleged art fraud and one which we address in some depth below. In Liberto it was an issue addressed by the Crown calling expert scientific evidence which suggested the paintings were indeed painted by someone other than Rover Thomas, and most likely by the accused.

The jury ultimately convicted the Libertos of all of the offences with which they were charged - a verdict which the presiding judicial officer, County Court Judge Williams, said included a finding by the jury that the art works were painted by the two accused (Liberto at 3). Judge Williams described the offences as 'deeply premeditated and highly planned', and at a significant cost 'to innocent third parties, in this case the auction houses, and at another general cost to the integrity of the art industry, in particular the Aboriginal art industry which must suffer when this sort of activity is brought to light' (Liberto at 3). The Libertos were sentenced to a cumulative total of three years imprisonment of which two years and three months were suspended.

\section{Further Tools in the Box?}

It should be emphasised that the range of offences utilised in the successful prosecution of O'Loughlin and the Libertos is only indicative of the legal tools available to law enforcement investigators and prosecutors involved in this area of fraud, and that in each jurisdiction it will be necessary to undertake a detailed examination of the contents of the local tool kit to see which item best fits the needs of a particular case. For example, no use would seem to have been made to date in Australia of the common law offence of conspiracy to defraud, or the statutory formulations of conspiracy in the jurisdictions with a criminal code (see in general Bronitt \& McSherry 2001:445-446). Nor has use been made of the law of forgery, or various civil law actions which might be brought against fraudsters.

\section{Some Issues with Words}

Those engaging in professional work addressing cases of art fraud will have to negotiate a discursive terrain that is cluttered with meanings that may cause occasional confusion. There are many popular words used, especially in contemporary media, with a looseness that is not helpful, two of these being 'forgery' and 'fakery'.

\section{Forgery}

The literature on art fraud is replete with descriptions of 'art forgers', 'art forgeries', 'forged painting' and similar terms. Indeed, one of the better known perpetrators of art fraud, Eric Hebborn (1997), used as a title for one of his books The Art Forger's Handbook. Commentators, such as Thomas Hoving (1996), use the term 'forgery' interchangeably with other words used to describe art fraud, and even legal writers (who might be expected to know better) follow this practice (see Spencer 2004:198, who comments on an English case where a court '... ruled the painting was a forgery ...'). The problem with this wide and common use of the term 'forgery' is found in English common law, where an early case, Closs (1857), found specifically (and perhaps peculiarly) that the term 'forgery' does not apply to works of art, but only to the forging of documents or writing. In the 1857 case, the defendant sold a painting on which appeared to be the signature of the artist, one John Linnell. The signature was in fact false. Even so, the court held that the case was not one of forgery, Chief Justice Cockburn asking rhetorically, 'can a sculpture be the subject of a forgery?' (at 1084). The court stated that: 
A forgery must be of some document or writing, and this was merely in the nature of a mark put upon the painting with a view of identifying it and was no more than if the painter put any other mark as a recognition of the picture being his' (at 1084).

This decision has since been criticised by legal scholars, it being suggested that the question whether an article, like a painting, is forged or not should be judged on whether it is 'purportedly authenticated in writing' (Lanham et al 1987:182). If this test had been applied in Closs, and in other cases where a false signature has been added to an art work, it would result in liability for uttering a forgery. Even so, those responsible for the formulation of the Model Criminal Code in 1995, confirming a view taken earlier by the influential United Kingdom Law Commission, made no recommendation to extend existing forgery provisions at large to include works of art like paintings, statues and similar objects (Model Criminal Code 1995:219).

It has also been suggested that some of the statutory formulations of the law of forgery adopted in certain Australian jurisdictions and in particular those with criminal codes (Queensland, Tasmania and Western Australia), make it possible that the narrow view expressed in Closs about the kind of article that can be forged could be reversed (Lanham et al 1987:183). A reversal of this type could only take place in a test case and at present no prosecutor in Australia would seem to have either been presented with an opportunity to raise such a challenge, or prepared to take the risk of losing the argument, about how far the law of forgery extends.

Even if the term 'forgery' was not to be applied to works of art (which we are not arguing, by the way), there are instances where art fraud cases, even under the common law principle in Closs, involve what is clearly forgery. One of the more recent important cases of serial art fraud in the United Kingdom was perpetrated jointly by Myatt (an artist who produced the works for the fraud) and Drewe (who managed the task of negotiating the false works onto the market) (see in general Landesmann 1999; Baker 1999:3-4). As a result of a successful prosecution, Drewe was convicted of two counts of forgery, as well as for other charges related to the fraud (see Guardian 1999). Such an action, that is the conviction for forgery, could be successful because moving works onto the art market involves not just art, but the documentation that supports the provenance of that art. While Myatt's part of the scheme was to produce the art works that were apparently convincing, Drewe had the responsibility for producing a wide range of false documents that established that the objects were 'genuine'. Drewe, thereby, could be charged with forgery concerning these documents even where the objects in question, applying the principle laid down in Closs, would be precluded from a prosecution for forgery.

\section{Fakery}

Rather different problems arise in the use of such terms as 'fake', 'faker', and 'fakery'. In this case the issues do not arise from the law, but from a tendency to use the term where it may not be appropriate, or exactly fit properly into the discussion. As commonly understood, the word 'fake' implies both that the work in question is not authentic, and that it has been intentionally produced to deceive. Consider how we use the word 'faker' to describe the actions of persons like De Hory, Hebborn or the Libertos. These were individuals who intentionally produced false works for the purposes of deceiving purchasers regarding the authorship and thereby, to use the legal phrase, 'obtain financial advantage'. Here the term 'faker' fits, and one can hardly argue with this common use.

The problem with such common terms occurs elsewhere. Consider the following case, as told by Kurz (1967:57). Sometime, probably in the 18 th or early 19 th centuries, an individual 
apparently attempting to increase the sale price of what was considered to be a not particularly distinguished Dutch painting, falsely attached to the work the signature of the then popular de Hooch. Some might consider the work from that point on to be a 'fake', since it is certainly not a de Hooch, except that the real author, indisputably, was Vermeer.

Another possibility, as occurred in a recent case involving the National Gallery of Victoria (NGV), is found where the work of one artist becomes identified as that of a more popular artist. In that example, a work which had for many years been identified as being done by Vincent Van Gogh was determined to be by another, unidentified, artist. In such circumstances the Gallery argues that while the painting is not a Van Gogh, neither should it be treated as a fake or forgery, since it is a legitimate work than can stand on its own (NGV 2007).

In an even more bizarre set of possible circumstances, Kurz (1967:37-38) recounts the tale of the events that transpired when the Duke of Mantua decided to have some of the finest paintings in his collection copied expertly and sent as a gift to the Spanish court. He passed on the task of conveying the paintings to a trusted ambassador, who was horrified when arriving in Spain to find that the works had been badly damaged by water during transit. The ambassador then used his not inconsiderable talents to restore the copies, in some cases being forced to create whole new works. Some of the resultant paintings are then copies of copies, while others have been extravagantly restored, which might earn them the term 'fake' (or even 'fakes of fakes'?) were it not for the fact that the ambassador was Peter Paul Rubens. If these were to be discovered generations later in some previously unknown collection, an initial assessment might be that as 'copies' or 'restorations' of earlier Italian works there is at a minimum an 'attribution problem', but that finding takes a very different twist when it is determined that the copying and restoration work was done by one of the greatest of the Flemish masters. (Hoving (1996:61) tells this story somewhat differently, but there is agreement with the Kurz account in terms of the fact that Rubens was called in to make copies of what had been copies - Hoving says that the original copyist was Pietro Facchetto, but neither Hoving nor Kurz identify the painters of the original art works.)

These diverse examples permit us to see where problems occur in the loose use of the term 'fake'. Using legal analogy, it can be seen that the common everyday application of this term combines a 'physical element' (an object which is not what it appears to be) and a 'mental element' (the intention to deceive for purposes of gaining financial advantage), when in fact in many situations only the physical element applies. While it may be possible to establish convincingly that the art in question is misattributed (that is, in some sense 'false'), at the same time there are circumstances where there may be no basis for the assumption that at the time of the examination anyone intended to use the object to deceive for purposes of gaining a financial advantage. A work may have been honestly copied for good motives in some early years, only to be mistakenly identified as the work of a more prestigious artist at a later date. Or, it may be the work has been so altered in the process of restoration (undertaken for sound reasons) that any claim of original authorship becomes clouded.

What such accounts make clear is the care that must be taken by art examiners in cases of art fraud in terms of what limits are placed on their findings. Since the expert witnesses are reporting on the examination of physical objects, their testimony (based on examination of provenance, connoisseurship, and scientific investigation) should in ordinary circumstances be limited to conclusions specifically about the physical elements of the claims of fraud, that is, is the art object what it claims to be, is it 'authentic'? The object itself obviously has no mental capacity. Whether or not there has been an intentional fraud, or that complicated 
word, 'dishonesty', requires evidence about individuals who are attempting negotiation of the object.

Any given work might re-enter the secondary art market several times. If that object is in fact not authentic, it only becomes a fraud when the person negotiating its sale knows it not to be authentic. It is thus theoretically possible for the same art work to be sold a number of times, and to be involved in a fraud for only some of those times. If the seller is not aware that the object is not authentic, there will be no fraud. In such a theoretical chain of events, the physical status of the work does not change. At no point does the work become 'authentic'. Put another way, as the term is commonly used, the work throughout this process is and remains a 'fake', but only under specific circumstances will the more demanding requirements of a fraud prosecution be met.

\section{Civil Suits}

Since the focus here is on the crime of fraud and its place in the art market, we have not addressed the possibilities of recourse to the civil process in situations where victims feel they have been taken in by unscrupulous dealers or other purveyors of art. Certainly there are some advantages of seeking resolution through a civil suit, among them that victims have a much greater (theoretical) chance of actual recovery of their funds, the burden of proof is lower in a civil case, and victims when they pursue a civil action have much greater (theoretical) influence on the process. Fraud itself is a matter that can be addressed by a civil action, and there are other options which might be considered, such as actions brought under s52(1) of the Trade Practices Act 1974 (Cth) which prohibits misleading and deceptive conduct in the course of trade and allied situations (McCausland 1999:2). The complexities of civil law are great, however, and space limitations do not permit even the barest of reviews of how cases involving disputes arising from the art market might play out in court (for a review of some cases arising in US and UK jurisdictions, see Spencer 2004). Despite the presence of these potential and as yet unused civil legal tools, dealing with art fraud and its associated unsavory manifestations is not an easy or simple matter, and nowhere is this more obvious than in coping with the issues of authenticity. It is to these issues which we now turn our attention.

\section{Deception in the Context of Art}

For a successful prosecution in a case of art fraud, attention early on will have to be paid to the issue of establishing beyond reasonable doubt that the defendant has engaged in deception. It is, of course, this element that provides the defining contours to a charge of art fraud, since the case will hinge on whether it can be determined that the art object offered to the victim is not what it appears to be. Further, it is the issue of the authenticity of a given work that brings the potential collision of two different worlds: the criminal justice system on the one hand, and the art world on the other. In addressing the question of deception, a court is likely to draw upon the professional knowledge of art experts such as conservators. Such experts are likely to have wide experience in assessing the authenticity of works of art (but may have a limited understanding of, and experience with, the legal system).

Art experts will draw upon three kinds of analysis in making their determination regarding the object or objects in question. First, they are likely to examine the provenance, or ownership history, of the items. This is most likely to be definitive in cases of well known 
works of highly regarded artists, especially where the works soon after creation have entered collections such as in public galleries, or in some cases important collectors, who appreciate the importance of careful record keeping. Even with works that have exceptional public value, however, there may be critical gaps (see, for an example, the discussion by Pitman suggesting that while much is known about the provenance of Raphael's 'St. George and the Dragon', at least 100 years of its early history are not known; Pitman 2006). Further, successful serial fraudsters will know the importance of provenance, and are likely to assemble either a reasonable story or even what appears to be convincing evidence of provenance. In the Drew/Myatt frauds, Drewe was able to enter the hard copy files in the libraries of major British collections and insert false documentation into what were otherwise legitimate catalogues of artists' work, Put simply, if fraudsters are able to create a successful fake work of art, they will have little trouble faking the provenance as well.

A second process used by art experts is to subject the object to scientific analysis. Over recent decades, exceptionally technical tools have been developed to assist art experts in the assessment of the authenticity of works. These might include chemical analysis of the pigments employed, photographic or x-ray (or other) analysis of the structure of the work, examination of the chemical composition of the canvas or paper that the work has been done upon, analysis of the structure of the wood used either in the frame or backing of the work, and so on. Historically, such scientific analysis has proven most useful where it can be definitively established that the work could not have been done by the artist or in the artist's time, for example, as where a pigment has been used that was not in existence at the time the work was supposed to have been done. Flescher (2004:96) puts the matter this way: 'Contrary to the layperson's perception, we have found sophisticated scientific tests to be far more effective in ruling out than ruling in'.

The third process used by such experts is to examine the object by means of stylistic analysis (which may to some degree draw upon scientific analysis as well). In this case the art experts are likely to draw upon their knowledge of how a given artist works, and whether the object being examined fits into their understanding of the common practices of the artist (for example, the way colours are used, the types of background employed, distinctive patterns or devices characteristic of the artist, etc), and the general expertise that the expert develops over time regarding the artist (sometimes referred to as 'connoisseurship', as by Flescher 2004:98).

There will be as a result of these various forms of analysis, three major possibilities that will confront potential prosecutions.

\section{The Work is Authentic}

One general possibility, of course, is that the work is fully authentic, in all of its aspects, and therefore no fraud is present. Thus, the object appears to be the work of the specified artist, perhaps it has the signature of the particular artist (assuming that the artist signed works), and in all other ways it conforms to the expectations of legitimate attribution.

A second related possibility is that the work is authentic, despite some contradictory evidence. For example, occasionally it is observed in the world of art that because of changing fads, signatures may be added, or taken away, that alter the appearance of authorship. As mentioned above, when an art dealer in some earlier time added the false signature of Pieter de Hooch to a genuine painting by Vermeer, an art authenticator would face a puzzle since the work is definitively a 'false' de Hooch, but a 'real' Vermeer. 
A third possibility is that the work, which appears initially to be a copy of another known work of the artist (and thus possibly a fraudulent copy), is in fact a further rendition by that artist of the subject. Thus, some artists were known to produce more than one copy of a particular scene or object (for examples, di Chirico, Monet, Renoir, Utrillo, the Canadian artist Krieghoff, or Van Gogh in the case of his 'Sunflowers'). In a recent further example, a painting previously thought to be a copy by another artist (because of another rendition of the same subject which is part of the collection of the Musees Royaux des Beaux-Arts in Brussels) was determined to be an authentic work by Frans Hals, and was then placed on the market at auction by Sotheby's London (Vogel 2008). The presence of many such renditions by an artist in the market can tempt a fraudster to add some additional objects (as Thomas Keating did with his 'Sexton Blakes' of Krieghoff, about whom he stated: '... he did so many versions of the same picture - so what difference was a few more going to make?'; Keating et al 1977:107).

\section{The Experts Can't Decide}

A professional assessing the authenticity of a work may occasionally encounter a situation where the various experts either cannot agree on a verdict, or over time, give contradictory judgments. The Metropolitan Museum in New York published a book a few years ago that essentially was a review of the arguments for and against the authenticity of a Chinese painting, 'Riverbank', in their collection (Smith \& Fong 1999). There was some consensus that the work was either a product of the 10th century master Dong Yuan (active in the 930s to 960 s), or an object created by the modern painter/fraudster Zhang Daqian (1899-1983). In short, the various experts called together to assess the work were unable to decide whether it was an authentic or fraudulent work. In such a case, of course, a court would be unable to decide even within the generous boundaries of 'the balance of probabilities' of a civil proceeding that the work was deceptive.

Probably the best known circumstances where there is expert disagreement concerns the findings of the Rembrandt Research Project. Rembrandt has been an obvious target for copyists and fraudsters, and some evidence of the problem faced by authenticators is shown by the fact that in the first half of the 20th century alone, a total of 9,428 of works claimed by his hand were imported into the US. Even as prolific as he was, this figure is totally improbable (Innes 2005:45). The highly respected scholarly and scientific work of the Rembrandt Project has served to reduce considerably the number of works now attributed to the artist, but their views are not always accepted by other authorities (for an overview, see Sutton 2004:29-38). The Frick Museum, in a notable example, rejected the suggestion that their 'The Polish Rider' is not by Rembrandt, and continued to display it as a work of that artist (for a discussion, see Bailey 1994). As an illustration of the confusion that can occur, a later and differently constituted Research Project subsequently changed its mind, and came to an assessment that the Polish Rider was a genuine Rembrandt, although others might have had a role in its creation.

\section{The Work is Not Authentic}

The third general possibility is that the work is not what it claims to be, that is, it is not authentic. It is only when this can be convincingly demonstrated in court that a prosecution for art fraud can be successful. The finding that a work is not authentic can arise from a number of quite different circumstances, only some of which might involve fraud. 


\section{The Problem of Copies}

A. The work may be a copy of an authentic work, created originally as a copy by a second artist without known fraudulent intent. On a visit to any major collection around the globe, one is likely to find persons in front of an easel engaged in the perfectly legitimate practice of copying the work of a known master. This is a well established tradition for the teaching and learning of art technique. Further, extending back into history this was a way of creating more art that was more accessible than is possible with one, often extremely expensive, rendition found in a public collection, or perhaps hidden away in a private collection.

Today one can find a number of outlets which offer 'genuine reproductions'. In China, currently, there is a large industry which has emerged in response to a demand for 'quality' paintings that are copies of famous originals. For example, in Xiamen, China, there are several firms that offer such reproductions on the market, especially through the internet (see the site: 'made-in-China.com'). For our purposes, the problem with these copies is that it can be all too easy, especially with older copies with uncertain provenance, for the work to find its way onto the art market where it becomes mistakenly identified.

B. A second possibility is that the work was created as a copy, but then either the object, or the documentation that accompanied it, was altered at a later date to change the apparent authorship (for example, by the addition of a false signature). That is, the original artist creating the work had the intent only of making a legitimate copy of the more famous work, but later there is a change (perhaps with fraudulent intent) which has an impact upon its authenticity.

C. A third possibility is that the famous work is copied, with the full intent of selling as a fraud. As an example of what would appear to be an excessive case, Kurz (1967:40) claims that Rohrich (1782-1834) created not just one spurious Cranach 'pretending' to represent the Duchess Sophie of Saxony, but then went on to produce '... about thirty identical versions'. A modern variation of this scenario was uncovered in New York in 2004, when the dealer Ely Sakhai was found to have purchased 25 separate original, authentic paintings with their proper provenance documents. Sakhai had the works expertly copied, and he then sold, first, the false, copied paintings with the genuine provenance documents, then at a later date he also sold the authentic original works (Thompson 2004; Usborne 2004).

D. A fourth form that such copies can take is that where inexpensive photographic copies are sold as art alleged to be produced by other means (for example, limited edition prints). Print making is a process of producing art through a printing process which might involve actual use of stone and ink, whereas the fraudulent copies, claimed to be prints, are produced by a 'photomechanical' process of reproduction (for an example, see the description of the sale of fraudulent works claimed to be prints by Dali, as discussed in Catterall 1992).

\section{The Problem of Alterations}

A further problem occurs when original legitimate works are altered, perhaps to the point where their authenticity must be questioned. Probably the most ubiquitous form of such alterations is that that occurs in the process of 'restoration'. While today this is a highly refined process, over the years some of the restorations are so extensive that there will inevitably be questions about how much of the work was done by the original artist, and how much is that of the restorer. Kurz (1967:40), in fact, has argued that the '... borderline between extensive restoration and forgery is difficult to draw'. Keep in mind that the current art examiner may be looking at a work that was restored in antiquity, and perhaps as well in 
more recent times, so that without doubt multiple artists have been at work on the object. Since many works have been restored, the problem for the art experts, and the courts, is to determine if the restoration work has been so extensive that the work may no longer be viewed, properly, as 'authentic'. This is illustrated in a recent case involving work done on a painting by Egon Schiele, where the judge decided that the restoration was significant enough so that the work could not be considered as authentic, although a major factor in the decision was that the restorer had altered the signature (Spencer 2004:189-215).

There are also instances where unfinished or abandoned works of one artist have been finished by another. When they died, both Tintoretto and El Greco left many unfinished canvases, which, according to Hoving $(1996: 57,58)$ were then completed by others in the artists' studios. The accomplished art fraudster Eric Hebborn recounts the story told by a friend of the English painter Walter Sickert of how Sickert, when on a walk, spotted across the street a painting that seemed familiar, and upon crossing the road discovered an early abandoned work of his that someone had found and finished, adding his signature. According to the story as told by Hebborn, Sickert asserted that he himself could not improve upon the work done, stating: 'Now I need never finish them any more and it often gives me quite a lot of trouble! I only wish I knew the name of the admirable artist who finishes and signs my things' (Hebborn 1997:xv, although the reader should be aware that Hebborn was known to occasionally stretch the truth).

The examiner's task can be complicated further when the painting is altered by a later artist so that elements are either added or taken away. There are numerous instances when a later artist will add clothing to naked figures (see discussion by Kurz 1967:41), or for other reasons of taste figures may either be added or removed from the painting by later artists. In all such cases, the work of the later artist is overlaid onto the original object, and can create significant problems in the assessment of its worth and authenticity.

\section{'Imagined Reproduction' or 'Pastiche'}

Probably the most common form of work done by serious, and serial, art fraudsters, what amounts to the master fakers, consists of creating a 'pastiche', where, rather than simply making a copy of a particular existing work, a new object instead is '... made in the manner of an artist' Chanin (1990:119). The Chinese over the centuries have been masters of such techniques, and Yang Ren-Kai (1997) suggests the term 'imagined reproductions' for these false works: Norman (1977:299), in her discussion of the use of pastiche by Keating, makes the point that all artists draw upon the achievements and experience of others, and there are many legitimate instances where it is difficult to tell the works of one artist from another, even when there has been no conscious attempt to copy or deceive. But further, to be a successful producer of fraudulent art, at the level of the likes of Keating, de Hory or perhaps Myatt:

[Y]ou must have a technical facility which equals or nearly equals that of the artist you are copying; moreover, you must have the spiritual sensitivity to assimilate, and to some extent share, his inspiration, in other words, you must be an artist (Norman 1977:200).

However they accomplish the task, it is the serial, pastiche fakers who create the greatest volume of mischief in the contemporary art market. Will Blundell in Australia, for example, who consistently referred to his works as 'innuendos' and was never charged with any crime over his pastiches, created hundreds of works in his career, and many of these can be presumed to be floating still in the Australian art market (Hills 2002). Similarly, fakers such as de Hory, Keating, or Drewe Myatt created hundreds if not thousands of works, of which an unknown quantity has still not been unmasked as false works. Interestingly, when works 
of such serial fraudsters re-enter the art market, there may be no fraud involved since the hopeful vendor of the work may be quite ignorant of the false origins of the art involved.

In actual prosecutions, these issues may present significant complexity. In both of the cases discussed in the opening sections, deception was alleged by the prosecution, arguing that the paintings in question had not been produced by the artists whose signatures were attached. How the cases actually play out depend upon the circumstances of the allegations. In the O'Louglin case the prosecution did not have to bring in experts to prove that the paintings were deceptive, since this was avoided by the plea of guilty (direct testimony of the artist that the works were false, of course, might have forced the hand of the defendant). In the case of the Libertos, a key part of the prosecution's case was the allegation that the paintings which had been sold as being works of Rover Thomas had not been done by that artist. To support this key element, testimony was sought from an expert witness (Robyn Sloggett, art conservator at the University of Melbourne) who argued that Thomas was not responsible for producing the works. What both cases demonstrate is that while the absence of authenticity is a key issue in art fraud (and thus must be established), other matters which relate to questions of intention may pose significant problems for successful prosecution outcomes.

\section{Art Fraud and the 'Dark Figure' Problem}

It is striking, of course, that a determination by the courts that an art fraud has been perpetrated is made so rarely, a fact which might become lost in the wave of media attention given to those few art fraud cases which come to public attention, such as the many articles covering the Libertos trial in Melbourne in late 2007, or the Greenhalg case in the UK (Shaun Greenhalg was sentenced to prison during the same month as the Libertos). Further, some of the claims made by at least some of the commentators may exaggerate the actual level of fraud. Hoving (formerly Director of the Metropolitan Museum), in his book on 'fake busting', claimed that 'fully 40 percent' of the literally thousands of works he had examined were either 'phonies or so hypocritically restored' that they could be considered as fakes (Hoving 1996:17). An even larger figure is claimed by Flescher (2004:99) who found that 'close to 80 percent' of the works submitted to the International Foundation for Art Research '... have been deemed not to be by the artist to whom they were attributed at the time of submission'. Robyn Sloggett, from the University of Melbourne, provides a more modest estimate in her observation that: 'About $10 \%$ of paintings on the market, both in Australia and internationally, are generally considered to be cases of mistaken identity' (as quoted by Porter 2007:18). As noted above in the various issues that arise in the examination of authenticity, there will be many circumstances of 'mistaken identity' that will not involve instances of fraud. Nonetheless, either 40 or even 10 per cent of nonauthentic works in the market would suggest a huge volume of potential art fraud.

There have been, in actual fact, only two known cases in recent years in Australia that we could identify where defendants have been charged and convicted of fraud involving art, the O'Loughlin case in NSW in 2001, and the Libertos in Victoria in 2007. There was, in addition, the report by Baker (1999) of a third case in Victoria in 1977 where an art dealer was convicted of five counts of fraud. A total of three cases in the entire country over a time span of 30 years hardly constitutes a crime wave.

This suggests a number of possibilities. For one, there is likely to be a large amount of unknown art fraud, or to use the phrase common in criminology, virtually all of art fraud is 
'dark figure' crime, that is, it is not to be found in official statistics of crime. Partly this is because if there were cases of such crime reported to authorities, and processed by the criminal justice system, any statistical reports would not contain a category of 'art fraud' or 'art crime' simply because the categories don't exist. It is possible, in other words, that there are reported art frauds that have been lumped into the general category of fraud and are thereby hidden from view (although we do not think this is the case). Another matter which is aggravated by the scarcity of cases is that police and prosecution are not likely to have experience or professional knowledge regarding art, and thus may be overly cautious in their approach to allegations of art fraud.

A compounding problem in art fraud, of course, is the rather unique position occupied by the victim. The role of the victim often is problematic in the criminal justice process. In many situations of property crime, however, such as burglary or car theft, victims may have financial reasons to be willing to report the crime (because of the possibility of recovery of the loss through insurance). In contrast, there are often good reasons for victims of art fraud not to report the crime to authorities. The identification of the work as fraudulent may have the instant result of seeing a large investment of money disappear. In the eyes of the victim, this financial loss might be avoided if the work is not identified as fraudulent, so that it might later be quietly placed back on the market with its original identity intact. There are many processes inherent in the art market that make this feasible, including the fact that art dealers often will protect the anonymity of purchasers of art works, and that the market works in such a way that there is a short memory for problematic works. There is, in addition, no mechanism by which suspected false objects are either removed from the market (as can happen in France where fake works may be destroyed) or permanently identified. In short, victims have a strong financial incentive not to report suspected art fraud.

Further, it must be kept in mind that serious art fraud involving large sums of money will by definition be focused on the secondary rather than the primary art market. In Australia, especially, that market is actually quite small. There are only a handful of auction houses, and roughly a dozen or so serious dealers, who will be playing a major role in that market. Thus, the 'portals' for entry of works are actually quite limited, and the serial offender has a real problem in moving works repeatedly onto the market. The major players in that market, as our interviews have shown over the years, are highly unlikely to buy items 'off the street', or from persons they have reason not to trust. Known access routes utilised by fakers become recognised very early by the important market figures, and they will eventually move to take steps to close down these portals (for example, in Brisbane a decade ago, one of the major dealers went to the police with complaints about an auction house that was being used for the movement of art he alleged was fraudulent onto the market). Put another way, not only is this secondary art market quite small, but there will be market mechanisms at work to restrict the access of that market to fraudulent works. As such, there are processes at work in the market itself which serve to reduce even the limited potential for fraud in the market, and thus the number of potential offenders.

Despite such considerations, it seems that the most reasonable conclusion is that when it comes to either numbers of frauds, or numbers of offenders, the 'real' figures are not likely to be large. Art fraud, in fact, is not an act that just anyone can carry off easily, especially systematic art fraud that involves multiple successful entries into the art market. For a person to pull off successful frauds, especially repeated frauds, they must be able to create goods of an acceptable standard of quality (that is, fraudulent art that will pass inspection by experienced curators or dealers), and they must have successful and repeated access to a 
market portal (such as a complicitous dealer, or an auction house willing to accept the work).

Having said that, this does not mean that there are but a few false works available on the market. The output of even a few of those creating fraudulent work has been huge. In Australia, Blundell (Hills 2002) alone is alleged to have created hundreds of false works that are, according to our sources, still circulating in the market (Blundell, it must be said, has never been prosecuted for his 'innuendos', and he has persistently claimed that any deceptive practices involving the objects he created were done by others). While at any specific time, the number of actual offenders producing false works may be small, the ultimate cumulative effect on the market has been quite large. When Hoving or Sloggett propose figures between 10 and 40 per cent, they are referring to the total proportion of 'misattributed' works which will be made up of many sources of error as well as fraud.

\section{Conclusion}

Art fraud is a crime that places particular and unique stress upon the wider community, the art market, and the criminal justice system. The general public tends to be ignorant of the nature of art fraud, and ambivalent about some of its practitioners. In part because of the information fed by the media, the lay community is not likely to understand the difference between misattribution and fraud, and tends to see fakes where that term is inappropriate. There seems to be a wide fascination with 'fakes' and 'fakers', but these concepts are often applied where they simply don't fit (hence our concern about these words). However careful the NGV was as it undertook the investigation of the painting that previously had been attributed to Van Gogh, in the public eye the painting, which is in fact a genuine and worthy 19th century work, has now become, in the eyes of many, a 'fake'.

The art market, too, has its ambivalences. On the one hand, there is real concern about the effect that a large number of fraudulent works will have on the market. There is always worry on the part of dealers that potential buyers will be frightened away from the market if the market can not be trusted. In our field work we met more than a few dealers who did not want even to discuss the issue of false works in the market for fear of the impact this might have on potential customers. Those connected with specific artists who become targets of fraud become especially concerned about the effects that such false works will have on the reputation (and then the sales) of such artists. On the other hand, addressing the problem of fraudulent art is not necessarily uncomplicated.

It is the belief of the present writers that in fact there are more than a few individuals currently in Australia producing false art, so that in other words, there is a significant 'dark figure' of art fraud. Wily players in local art scenes manage mostly to keep their frauds at a level low enough so that, apparently, the attention of the criminal justice system will not pick them up. When hundreds of thousands, or millions, of dollars are lost in insurance or bank frauds, who on a fraud squad has the time to run down an art fraud that appears to involve only a few thousand dollars? One of the tasks of criminologists, then, would be to document where it is possible the workings of the fraudulent component of the art market, and to attempt, as we have done, to suggest some practical steps whereby such fraud might be curtailed. 


\section{Cases}

Peters v The Queen (1998) 192 CLR 493

$R v$ Closs (1858) 169 ER 1082

$R v$ Feely [1973] QB 530

$R v$ Ghosh [1982] 3 WLR 110

$R v$ Ivan Liberto and Pamela Yvonne Liberto [2008] VCC 1372

$R v$ John Douglas O' Loughlin (2002) Unreported, NSWDC, 23 February 2002

$R v$ Salvo [1980] VR 401

\section{References}

Bailey A 1994 Responses to Rembrandt: Who Painted the Polish Rider? A Controversy Considered Timken Publishers New York

Baker P 1999 'Policing Fakes' a paper delivered at the conference 'Art Crime: Protecting Art, Protecting Artists and Protecting Consumers' sponsored by the Australian Institute of Criminology, Sydney, 2-7 December

Bronitt S \& McSherry B 2001 Principles of Criminal Law LBC Information Services Sydney

Catterall L 1992 The Great Dali Art Fraud and Other Deceptions Barricade Press Fort Lee, NJ

Chanin E 1990 Collecting Art: Masterpieces, Markets and Money Craftsman House Roseville NSW

Clunas C 1997 Art in China Oxford University Press Oxford

Flescher S 2004 'The International Foundation for Art Research' in Spencer RD (ed) The Expert versus the Object: Judging Fakes and False Attribution in the Visual Arts Oxford University Press Oxford

Guardian 1999 'Faker Who Flooded Art World Jailed for 6 Years' The Guardian 16 February <www.guardian.co.uk/uk/1999/feb.16/5/print> accessed 3 March 2008

Hagan K 2007a 'Couple accused of Selling Forged Paintings' The Age 24 October <www.theage.com.au/articles/2007/10/23/1 192941066146.html> accessed 7 June 2008

Hagan K 2007b 'Word of Accused Art Forgers Good enough for Expert' The Age 25 October <www.theage.com.au/articles/2007/10/24/1192941153105.html> accessed 7 June 2008

Hagan K 2007c 'Forgers Used Sand for that Desert Finish, Court Told' The Age 26 October <www.theage.com.au/articles/2007/10/25/1192941243921.html> accessed 7 June 2008

Hebborn E 1997 The Art Forger's Handbook Cassell London 
Hills B 2002 'Judge Gives Go Ahead to Sell 1000 Fake Paintings' Sydney Morning Herald 23 May <www.smh.com.au/articles/2002/05/22/1022038435765.html> accessed 30 June 2008

Howie R \& Johnson P 2008 Annotated Criminal Legislation: New South Wales LexisNexis Butterworths Sydney

Hoving T 1996 False Impressions: The Hunt for Big-Time Art Fakes Simon \& Schuster New York

Innes B 2005 Fakes and Forgeries: The True Crime Story of History's Greatest Deceptions Amber Books London

Irving C 1969 Fake!: The Story of Elmry de Hory the Greatest Art Forger of Our Time McGraw-Hill New York

Keating T, Norman F \& Norman G 1977 The Fake's Progress: Being the Cautionary History of the Master Painter and Simulator Mr Tom Keating Hutchinson London

Kurz O (1967) Fakes Dover New York

Landesman P 1999 'A 20th-Century Master Scam' New York Times Magazine 18 July $<$ http://query.nytimes.com/gst/fullpage.html?res=9401E1DF113CF93BA25754C0A96F $958260>$ accessed 8 June 2008

Lanham D, Weinberg M, Brown K \& Ryan G 1987 Criminal Fraud Law Book Company Ltd Sydney

McCausland S 1999 'Adelaide Art Dealer Charged over Clifford Possum Paintings' 1999 Indigenous Law Bulletin 83

Model Criminal Code Officers Committee of Attorneys General 1995 Model Penal Code, Final Report December 1995 Chapter 3 'Theft, Fraud, Bribery and Related Offences (Australia)' Officers Committee of Attorneys General Canberra

National Gallery of Victoria (NGV) 2007 'Not a Forgery, but not a Van Gogh' Gallery Magazine September/October p 10

Norman G 1977 'Art Trading and Art Faking' in Keating T, Norman F \& Norman G (eds) The Fake's Progress: Being the Cautionary History of the Master Painter and Simulator Mr Tom Keating Hutchinson London

O,Connor FV 2004 'Authenticating the Attribution of Art: Connoisseurship and the Law in the Judging of Forgeries, Copies and False Attributions' in Spencer RD (ed) The Expert versus the Object: Judging Fakes and False Attribution in the Visual Arts Oxford University Press Oxford

Pitman J 2006 The Raphael Trail: The Secret History of One of the World's Most Precious Works of Art Random House London

Porter L 2007 'Art imitating art' The Sunday Age 2 December p 18

Smith JG \& Wien CF 1999 Issues of Authenticity in Chinese Painting Metropolitan Museum of Art New York

Spencer RD (ed) 2004a The Expert versus the Object: Judging Fakes and False Attributions in the Visual Arts Oxford University Press Oxford 
Spencer RD 2004b 'The Risk of Legal Liability for Attributions of Visual Art' in Spencer RD (ed) The Expert versus the Object: Judging Fakes and False Attributions in the Visual Arts Oxford University Press Oxford

Sutton P 2004 'Rembrandt and a Brief History of Connoisseurship' in Spencer RD (ed) The Expert versus the Object: Judging Fakes and False Attributions in the Visual Arts Oxford University Press Oxford

Thompson C 2004 'How to Make a Fake' New York Times 24 May p 18

Usborne K 2004 'Great Impressionist? New York art dealer faces trial for forgery' Independent (London) 12 March p 6

Vogel C 2008 'Adding One More Work to Hal's Portfolio' New York Times 30 May $<$ www.nytimes.com/2008/05/30/arts/design/30voge.html> accessed 3 February 2009

Yang Ren Kai 1997 Genuine and Fake Illustrated Dictionary of Chinese Calligraphy and Paintings in Every Dynasty Liaoning Picture Press Liaoning 